\title{
Potential risk factors of food allergy in children: EuroPrevall project results in Vilnius, Lithuania
}

\author{
Andrius Kavaliūnas ${ }^{*}$, Genè Šurkienè, Rūta Dubakienè, Kęstutis Žagminas, Rimantas Stukas \\ Faculty of Medicine, Vilnius University, Vilnius, Lithuania; 'Corresponding Author: andrius.kavaliunas@gmail.com \\ Received 30 October 2013; revised 29 November 2013; accepted 2 December 2013 \\ Copyright (C) 2013 Andrius Kavaliūnas et al. This is an open access article distributed under the Creative Commons Attribution Li- \\ cense, which permits unrestricted use, distribution, and reproduction in any medium, provided the original work is properly cited.
}

\begin{abstract}
Objectives: In recent decades, the prevalence of allergic diseases, including food allergy, has been increasing. This is becoming an important health problem. Many risk factors of food allergy were identified recently, and many of them still are controversial. The aim of this study was to evaluate the potential risk factors of food allergy in child population following the methodology of the EuroPrevall project. Methods: Vilnius University was a partner in the EuroPrevall integrated project "The prevalence cost and basis of food allergy in Europe", which is an EU-funded multi-disciplinary research study. A case-control study design was used to address the study question. All subjects were assessed by means of questionnaire and blood sample test for specific immunoglobulin E. Possible risk factors like mother's addictions (smoking, alcohol drinking during pregnancy), infant low birth weight and nursing duration, gender, treatment with antibiotics during first two years of life were analysed. Multiple logistic regression was used for risk factor analysis. Results: No statistically significant associations were found between risk factors and food allergy. Only gender (male) (ORa $=3.36,95 \% \mathrm{Cl} 1.17-9.63$ ) and mother's food allergy (ORa $=5.44,95 \% \mathrm{Cl} 1.19-24.97$ ) were directly associated with child's food allergy. Because of the presence of those both two factors (gender (male) + mother's allergy), the risk for food allergy increased particularly-OR was 18.31 (95\% Cl 2.01 - 166.07). Conclusion: Gender (male) and mother's food allergy are the most important risk factors directly associated with children's food allergy.
\end{abstract}

Keywords: Food Allergy; Epidemiology; Risk Factors; Children

\section{INTRODUCTION}

In recent decades, the prevalence of allergic diseases, including food allergy, has been increasing. This is becoming an important health problem [1]. The main risk factors that contribute to this are as follows: genetic predisposition, allergen exposure, environmental pollutants, and low immune response of the individual critical periods of development. Therefore, allergies can be treated as a disease of modern civilisation, and it is proposed to apply the concept of common health disorder to them [2].

It is thought that the number of foods that can cause allergic reactions is growing, and the number of serious allergic reactions is increasing, but reliable information on precise magnitude of this problem is missing. The prevalence of food allergies in children, especially in younger age, is a major interest, since different studies show that it is higher in adults. Along with all the social and economic implications for public health, the prevention and treatment of adverse reactions to food are becoming a challenge to scientists, doctors, policy makers, and the public [3].

According to the results of the International Study of Asthma and Allergies in Childhood (ISAAC), allergy symptoms are more prevailing in Western Europe in comparison to non-polluted rural areas and former Social states in Central and Eastern Europe and Finland, including industrial cities in Poland, Estonia and Russia [4]. Survey data show that $3 \%$ to $35 \%$ of adults believe that they or their children suffer from food allergies, although accomplished studies on this particular issue report that $6 \%$ to $8 \%$ of young children (up to 3 years), $3 \%$ to $5 \%$ of older children and in $1.5 \%$ to $3 \%$ of adults are really allergic to food. However, it is difficult to assess the exact prevalence of food allergy because of the regional disparities, as well as differences in the epidemiological data and research methods. It should be noted that food allergy is often identified to people with other atopic diseases: food allergy is diagnosed to $33 \%$ to $40 \%$ 
of children and young adults with moderate or severe atopic dermatitis, and about $6 \%$ to $17 \%$ of children with asthma [5-8]. Thus, the disparities in the prevalence of these allergic diseases as well as an abundance of new allergens, determine the need to continue to study more this particular issue.

There are not many studies done in Lithuania to determine a consistent pattern of allergies. Moreover, there is lack of data about the epidemiology of food allergy and its risk factors.

The aim of this study was to evaluate the association between food allergy and its potential risk factors, like mother's addictions (smoking, alcohol drinking during her pregnancy), infant low birth weight and nursing duration, gender, treatment with antibiotics during the first two years of life.

\section{MATERIALS AND METHODS}

Vilnius University was partners in the EuroPrevall integrated project "The prevalence cost and basis of food allergy in Europe", which is an EU-funded multi-disciplinary research study. To ensure methodological integrity of the study, all participating centres followed the EuroPrevall Manual of Procedures and consolidated methodology [9]. The study focused on IgE-mediated allergies to a number of foods most commonly reported to cause Type I allergic reactions. The foods selected included many which have to be labelled in the EU, such as cow's milk, hens' egg, fish (cod), shrimp, peanut, hazelnut, walnut and celery. In addition, two stone fruits, apple and peach, were selected since these represent foods involved in cross-reactive allergies. Furthermore, sensitization to a panel of other foods, including soy, wheat, buckwheat, corn, carrot, tomato, melon, kiwifruit, banana, lentils, sesame seeds, mustard seeds, sunflower seeds, and poppy seeds was examined. An approval of the Lithuanian Bioethics Committee was obtained to conduct this biomedical research (21 December 2005; No. 60).

\subsection{Design}

In order to accomplish our aim, a community-based survey was carried out with a specially composed questionnaire for self-reported adverse reactions to food. The survey included data from 4333 children of 13 primary schools in Vilnius (out of the 16). In total, 3084 questionnaires were used ((response rate was $71.2 \%$ ) for further analysis. Participant for the further cases-control study were selected from this actual study population. From the total 814 selected children, 205 (31.3\%) of children's parents agreed to take part in the further study, although after familiarising with the information sheet and consent form, 19 parents of children refused to per- form blood test for their child, 29 refused to be interviewed.

Firstly 209 children, who reported to have had an ailment or a trouble caused by eating a food or foods from the 25 foods listed above, were chosen for the further study. There were also another 605 children matched by sex, age and the school, those who did not report to have had an ailment or a trouble caused by eating a food or foods from the 25 foods.

\subsection{Data Collection}

Selected participants, those reporting to have had illness or trouble caused by eating a food or foods and those reporting not to have such problems, were invited to take part in the case-control study, which included the interview and taking blood samples. Selected persons were contacted by phone to agree on subsequent meeting.

Special questionnaires, created and approved for this project by Institute of Food Research (Norwich, UK), were used in all participating countries. To ensure the validity of questionnaires, standardized translation procedures, involving forward translation (from English into Lithuanian), backward translation (comparison and necessary editing), and local piloting, were done. Our questionnaire was a comprehensive tool for interview and contained different groups of questions about ones childhood, family, home, environment, work, health and diseases, etc., including such potential risk factors as mother's smoking during pregnancy, mother's alcohol drinking during pregnancy, infant birth-rate, breast feeding and others for development of food allergy.

\subsection{Laboratory Studies}

Collection of blood samples was performed at Allergy centre in Vilnius University Antakalnis Hospital. All data were encoded, and the blood samples were labelled with bar codes to ensure confidentiality. No identifiable data were put on the questionnaires or samples. The next of kin, caretakers, or guardians were asked to sign a written consent form on a behalf of their children before starting interview and blood sampling. The results of tests were considered positive if specific antibody level in serum was $\geq 0.35 \mathrm{kUA} / \mathrm{l}$. A two-step approach was taken to reduce the number of tests required to assess sensitization to foods. First, the samples were screened using five food mixes to identify samples with elevated specific IgE antibody levels. Samples testing positive to a mix were subsequently tested against the individual foods of that mix. The levels of serum IgE were measured using an ImmunoCAP 250 system at a central laboratory, Academic Medical Centre in Amsterdam. 


\subsection{Data Analysis}

In this article we present data on potential risk factors from the case-control study. All those participants, that agreed to take part in, were grouped into cases and controls for the analysis of the risk factors according to the results of blood samples. Case was defined as a child, who reported to have had an ailment or a trouble caused by eating a food or foods and with the positive result of blood sample (specific antibody level in serum was $\geq 0.35 \mathrm{kUA} / \mathrm{l})$. All other children, that did not report to have had an ailment or a trouble caused by eating a food or foods, and those, who did report but with the negative results of blood sample (specific antibody level in serum was $<0.35 \mathrm{kUA} / \mathrm{l}$ ) were defined as controls in the data analysis.

We used stepwise multiple logistic regression with backward elimination for model building. Two-way contingency tables were used for categorical variable selection. All variables significant at the alpha level of 0.3 were entered into multiple logistic regression model. The results are presented as OR with 95\% CI. A 5\% level of significance was used for all analyses. The statistical data analysis was performed using a statistical package Stata 10.1 .

\section{RESULTS}

There were 92 (46.7\%) boys and 105 (53.7\%) girls, from 7 to 12 years age (average age $-9.3 \pm 1.3$; median-9 years), in the children group. After the analysis of blood tests, sensitization to food was identified to 42 $(22.6 \%)$ children. Other details of the cases and controls groups are presented in Table 1. Table 2 shows the results of bivariate analysis on association between selected risk factors and food allergy.

Mother's smoking during pregnancy, as a risk factor, was more common among those children with identified food allergy than among those with no food allergy. It was determined, that $6.3 \%$ of mothers whose children had food allergy and $2.4 \%$ of mothers whose children had not food allergy were smoking during the pregnancy, but there was no significant statistical association between mother's smoking during pregnancy and her child suffering from food allergy $(\mathrm{OR}=2.69 ; 95 \%$ CI $[0.63$ 13.89]; $\mathrm{p}=0.272$ ).

The prevalence of mother's alcohol drinking during pregnancy was $9.4 \%$ in a group of children with food allergy and $15.3 \%$ - in a group without it $(p=0.57)$. Still, mother's alcohol drinking during pregnancy did not increased odds for their child to develop this disease (OR = $0.57 ; 95 \%$ CI [0.15 - 1.75]).

The prevalence of low birth weight (birth weight under $2499 \mathrm{~g}$ ) was $3.1 \%$ in children with food allergy and $6.5 \%$ in non-allergic children $(\mathrm{p}=0.686)$. But low birth rate did not increase odds to develop food allergy (OR = $0.46 ; 95 \%$ CI [0.26 - 2.59]).

Table 1. Details of cases and controls.

\begin{tabular}{ccc}
\hline & Cases (\%) & Controls (\%) \\
\hline Boys & $22(57.9)$ & $62(44.3)$ \\
Were born in Lithuania & $31(96.9)$ & $125(100)$ \\
Mothers were born in Lithuania & $30(93.8)$ & $122(97.6)$ \\
Lived in inner city most of the time when he/she was under the age of two years & $16(50.0)$ & $65(52.0)$ \\
\hline
\end{tabular}

Table 2. Risk factors of food allergy in children.

\begin{tabular}{|c|c|c|c|c|c|}
\hline Risk factor & Cases $(\%)$ & Controls $(\%)$ & OR & $95 \% \mathrm{CI}$ & $\mathrm{p}$ \\
\hline Gender (boys) & $22(57.9)$ & $62(44.3)$ & 1.73 & $0.81-3.82$ & 0.136 \\
\hline Mother smoke during her pregnancy & $2(6.3)$ & $3(2.4)$ & 2.69 & $0.63-13.89$ & $0.272^{*}$ \\
\hline Mother drank alcohol during her pregnancy & $3(9.4)$ & $19(15.3)$ & 0.57 & $0.15-1.75$ & $0.570^{*}$ \\
\hline Low infant birth-weight $(<2.5 \mathrm{~kg})$ & $1(3.1)$ & $8(6.5)$ & 0.46 & $0.26-2.59$ & $0.686^{*}$ \\
\hline Shorter duration of breast-feeding ( $\leq 4$ months) & $18(56.2)$ & $57(46.0)$ & 0.66 & $0.28-1.55$ & 0.327 \\
\hline Mother had asthma & $2(6.2)$ & $7(5.7)$ & 1.1 & $0.32-4.60$ & $>0.999^{*}$ \\
\hline Mother had food allergy & $8(26.7)$ & $19(17.1)$ & 1.76 & $0.63-4.40$ & 0.238 \\
\hline Anyone smoke in the family during first 2 years of life & $8(26.7)$ & $39(31.5)$ & 0.79 & $0.23-1.82$ & 0.61 \\
\hline Child was given antibiotics in the first two years of life & $22(68.8)$ & $89(71.8)$ & 0.87 & $0.37-2.38$ & 0.736 \\
\hline
\end{tabular}

*Fisher's exact test. 
When assessing the prevalence of food allergy and its association with the duration of breast-feeding, we took 4 months' limit and grouped children into two groups: one with children, who were fed naturally shorter than 4 months (or were not fed naturally at all), and the other group with children, that were fed naturally 5 months or longer. $56.2 \%$ of children to whom food allergy was identified, were fed naturally for a shorter period. Although shorter duration of breast-feeding was not associated with food allergy $(\mathrm{OR}=0.66 ; 95 \%$ CI $[0.28-1.55]$.

There were also no significant associations found when analysing other potential risk factors - mother's asthma, mother's food allergy, treatment with antibiotics during the first 2 years of life, anyone smoking in the family during first 2 years of life, gender. Similar results with no significant associations were observed in adults group. Multivariate analyses are listed in Table 3. Logistic regression model was statistically significant only with these independent variables: child gender and mother's food allergy. Gender (male) $(\mathrm{OR}=3.36)$ and mother's food allergy $(\mathrm{OR}=5.44)$ were directly associated with child's food allergy. But on the presence of those both two factors (gender + mother's allergy), risk for having food allergy increases particularly $(\mathrm{OR}=18.3$; 95\% CI [2.02 - 166.04]).

\section{DISCUSSION}

Many risk factors of food allergy were identified recently, and many of them still are controversial. Lifestyle has a great influence to the development of allergies. In developing countries, allergies are far more common among people living in better social conditions, e.g., allergies are less common among children living in the UK, that migrated from West India, than among their brothers and sisters that were born in England [10]. Therefore it is considered that the environmental conditions have the greatest impact in early childhood.

Why immunoglobulin $\mathrm{E}$ ( $\mathrm{IgE}$ ) antibodies form against food proteins is still not completely clear. One of the oldest and best known is the hygiene hypothesis. According to this explanation, improved hygiene, as well as

Table 3. Adjusted model: food allergy = "child gender and mother's food allergy" and linear combinations of gender relative to mother's food allergy.

\begin{tabular}{cccc}
\hline Risk factor & $\mathrm{OR}_{\mathrm{C}}$ & $\mathrm{OR}_{\mathrm{A}}$ & $95 \% \mathrm{CI}$ \\
\hline Gender (male) & 1.73 & 3.36 & $1.17-9.63$ \\
Mother had food allergy & 1.76 & 5.44 & $1.19-24.97$ \\
$\begin{array}{c}\text { Linear combination: } \\
\text { Gender (male) + mother's food allergy }\end{array}$ & - & 18.31 & $2.01-166.07$ \\
\hline
\end{tabular}

$\mathrm{OR}_{\mathrm{C}}$ - crude odds ratio; $\mathrm{OR}_{\mathrm{A}}$ - adjusted odds ratio. Logistic regression model: $\mathrm{n}=126$, Likelihood-ratio $\chi^{2}=8.12 ; \mathrm{df}=3 ; \mathrm{p}=0.0436$. increasing volume of the vaccination, determines such situation, that the immune system is not exposed or too rarely "meet" with the usual pathogens, parasites, and instead develops sensitivity to conventional antigens, e.g., food [11]. Besides the widely known hygiene hypothesis, food allergy is often reviewed and assessed in relation to other atopic diseases, breast-feeding and diet, early use of antibiotics and other environmental and lifestyle factors $[12,13]$.

Research has shown that one of the main risk factors for the development of allergic diseases is heredity [14-16]. By previous survey in Vilnius, it was found, that there were 2 times more allergic children in families with allergic members in comparison with families in which no one had allergy [17]. So, if at least one parent is allergic, there is a great likelihood, that their child cannot avoid this problem. In concordance with that, mother's food allergy was proven to be a potential risk factor (OR $=5.44$ ) for child's food allergy in our study.

Another important risk factor for food allergy in our study was gender-male $(\mathrm{OR}=3.36)$. After summarizing other studies, that were tackled for determining the correlation between incidence of allergic diseases (especially asthma), and sex, we found similar results-little boys are prone to the disease more often than girls, although currently it is not clear which factors have a decisive influence. There is an opinion that this may be caused by physiological changes in mothers; boys' narrower airways, increased tonicity of bronchi or possibly higher IgE levels in the blood, leading to changes in the bronchial lumen in response to various stimuli, including changes in sex hormones during growth and maturation time. However, these changes disappear as the child grows, and about ten years, the boys suffer from allergies or indicate specific symptoms of allergic illnesses similar to that of girls, and later on, from 12 years, some allergic symptoms begin to occur more frequently in girls and women [18-20]. More prevalent symptoms of bronchial asthma, allergic rhinitis and atopic dermatitis in $6-7$ years boys and in 13 - 14 years girls were also determined in Kaunas, Lithuania [21,22], more prevalent home allergies among boys than girls were found out in Vilnius [23]. More prevalent food allergy among boys than girls was also found in Finland [24].

In our study we evaluated such risk factors, as mother's smoking and alcohol drinking during pregnancy, infant birth weight, breast-feeding, antibiotic treatment and others. The association between them and food allergy was not identified. Other scientists also investigate possible causes of allergic diseases. For example, researchers in Kaunas were searching for the association between mother's smoking and child's bronchial asthma, allergic rhinitis and allergic dermatitis, and the link was not found, although children, that were treated with anti- 
biotics during the first years of their life, more often had bronchial asthma and atopic dermatitis [25]. It is known that in recent decades there was a significant increase in the use of antibiotics to treat children's upper respiratory tract infections. Many authors consider that antibiotics cause changes in intestinal microflora, thus creating favourable conditions to prevail Staphylococcus aureus and coliforms, which may contribute to allergic diseases such as asthma, atopic dermatitis or rhinoconjunctivitis, however, links to food allergy were not found [12,2628].

Ip et al., after analyzing more than 9000 studies conducted in developing countries, say that breast-feeding reduces the risk not only for gastroenteritis, enterocolitis, respiratory tract infections, ear infections, but also for atopic dermatitis, diabetes, leukemia and even sudden infant death syndrome [29]. However, there are a number of studies, with controversial results, by which breastfeeding's prophylactic value to allergic diseases has not been demonstrated [30]. After full-term infants study in Kaunas it was determined that breast-feeding is associated with lower incidence of infants' infections, but was not associated with allergies [31]. However, children's allergy to cow's milk, which has been particularly common in the first quarter of the twentieth century, especially due to the frequent feeding with infant formula, now is significantly reduced, because of the popular breast-feeding. Fewer children who have had at least 3 months of breast-feeding, had atopic dermatitis being at the age of one year [32]. The European Academy of Allergy and Clinical Immunology, European Society of Paediatric Allergy and Clinical Immunology, European Society for Paediatric Gastroenterology, Hepatology and Nutrition and the World Health Organization recommends breast-feeding until 6 months, or at least 4 months $[30,33]$.

A number of studies seek to identify the correlation between low birth weight and food allergies. In 2007, Canadian researchers, referring to the fact that premature infants have increased intestinal permeability compared them with normal-weight newborns, sought to determine whether premature birth and low birth weight affect the occurrence of food allergies. However, the hypothesis was rejected because of the fact, that from 13,980 low birth rate newborns who were followed from 1995 to 2002 , only 316 (4.23\%) developed food allergies. Researchers have published the conclusion that neither the duration of pregnancy, nor the infant birth weight are risk factors for food allergies [34].

Following research data of German scientists, maternal alcohol consumption during pregnancy was not associated with the development of eczema, but this disease was much more common among children whose families had members with allergic diseases [35].
It should be noted that many of the scientific literature and research data on risk factors that are associated with allergic diseases, are evaluated as a whole, and many of risk factors of allergic disease are considered as the risk factors for food allergy in general [12], although it is a lack of detailed epidemiological food allergy studies (except reviews), using predictive models of risk factors in their assessment and relationship with the disease.

Self-selection bias was a small but real problem in our study. Adverse reactions to food and food hypersensitivity are usually more prevalent than food sensitization and IgE mediated food allergy in general society, therefore people, suffering from food hypersensitivity and/or often experiencing ailments, caused by eating a food or foods, could wish to take part in the study, especially in the clinical part of it, more actively.

A double blind placebo controlled food challenge, remaining the gold standard for the diagnosis of food allergies, was not used in this study, as we looked to it with more epidemiological approach, rather than diagnostic.

\section{CONCLUSION}

Gender (male) $(\mathrm{OR}=3.36)$ and mother's food allergy $(\mathrm{OR}=5.44)$ are the most important risk factors directly associated with child's food allergy. Because of the presence of those both two factors (gender + mother's allergy), risk for food allergy increases in particular.

\section{ACKNOWLEDGEMENTS}

This epidemiological study was conducted within the collaborative research initiative EuroPrevall, an integrated project, funded by the European Commission under the 6th Framework program (contract FOOD-CT-2005-51400).

\section{REFERENCES}

[1] Rudzevičienè, O. (2009) Alergija maistui, Vilniaus universiteto leidykla, Vilnius.

[2] Kanceljak-Macan, B. (2004) Current views on allergic diseases. Arhiv za Higijenu Rada i Toksikologiju, 55, 123134.

[3] Mills, E.N., Mackie, A.R., Burney, P., Beyer, K., Frewer, L., Madsen, C., Botjes, E., Crevel, R.W. and van, R.R. (2007) The prevalence, cost and basis of food allergy across Europe. Allergy, 62, 717-722. http://dx.doi.org/10.1111/j.1398-9995.2007.01425.x

[4] Bjorksten, B. (1999) The environmental influence on childhood asthma. Allergy, 54, 17-23. http://dx.doi.org/10.1111/j.1398-9995.1999.tb04383.x

[5] Asero, R., Ballmer-Weber, B.K., Beyer, K., Conti, A., Dubakiene, R., Fernandez-Rivas, M., Hoffmann-Sommergruber, K., Lidholm, J., Mustakov, T., Oude Elberink, J.N., Pumphrey, R.S., Stahl, S.P., van, R.R., Vlieg-Boer- 
stra, B.J., Hiller, R., Hourihane, J.O., Kowalski, M., Papadopoulos, N.G., Wal, J.M., Mills, E.N. and Vieths, S. (2007) IgE-mediated food allergy diagnosis: Current status and new perspectives. Molecular Nutrition \& Food Research, 51, 135-147. http://dx.doi.org/10.1002/mnfr.200600132

[6] Crespo, J.F. and Rodriguez, J. (2003) Food allergy in adulthood. Allergy, 58, 98-113. http://dx.doi.org/10.1034/j.1398-9995.2003.02170.x

[7] Schafer, T., Bohler, E., Ruhdorfer, S., Weigl, L., Wessner, D., Heinrich, J., Filipiak, B., Wichmann, H.E. and Ring, J. (2001) Epidemiology of food allergy/food intolerance in adults: Associations with other manifestations of atopy. Allergy, 56, 1172-1179. http://dx.doi.org/10.1034/j.1398-9995.2001.00196.x

[8] Sicherer, S.H. and Sampson, H.A. (2010) Food allergy. Journal of Allergy and Clinical Immunology, 125, S116S125. http://dx.doi.org/10.1016/j.jaci.2009.08.028

[9] Kummeling, I., Mills, E.N., Clausen, M., Dubakiene, R., Perez, C.F., Fernandez-Rivas, M., Knulst, A.C., Kowalski, M.L., Lidholm, J., Le, T.M., Metzler, C., Mustakov, T., Popov, T., Potts, J., van, R.R., Sakellariou, A., Tondury, B., Tzannis, K. and Burney, P. (2009) The EuroPrevall surveys on the prevalence of food allergies in children and adults: Background and study methodology. Allergy, 64, 1493-1497. http://dx.doi.org/10.1111/j.1398-9995.2009.02046.x

[10] Strachan, D.P. (1999) The epidemiology of childhood asthma. Allergy, 54, 7-11. http://dx.doi.org/10.1111/j.1398-9995.1999.tb04381.x

[11] Lack, G. (2008) Epidemiologic risks for food allergy. Journal of Allergy and Clinical Immunology, 121, 13311336. http://dx.doi.org/10.1016/j.jaci.2008.04.032

[12] Cochrane, S., Beyer, K., Clausen, M., Wjst, M., Hiller, R., Nicoletti, C., Szepfalusi, Z., Savelkoul, H., Breiteneder, H., Manios, Y., Crittenden, R. and Burney, P. (2009) Factors influencing the incidence and prevalence of food allergy. Allergy, 64, 1246-1255. http://dx.doi.org/10.1111/j.1398-9995.2009.02128.x

[13] Dubakienè, R., Vaicekauskaite, D., Zidanavičiūtè, J., Joneliūnienè, I., Drasutienė, G., Arlauskienė, A., Zakarevičienè, J. and Kondrotas, A. (2006) Human ecology studies: The role of the environmental factors in pregnancy. Ekologija, 4, 18-21.

[14] Girolomoni, G., Abeni, D., Masini, C., Sera, F., Ayala, F., Belloni-Fortina, A., Bonifazi, E., Fabbri, P., Gelmetti, C., Monfrecola, G., Peserico, A., Seidenari, S. and Giannetti, A. (2003) The epidemiology of atopic dermatitis in Italian schoolchildren. Allergy, 58, 420-425. http://dx.doi.org/10.1034/j.1398-9995.2003.00112.x

[15] O'Connell, E.J. (2003) Pediatric allergy: A brief review of risk factors associated with developing allergic disease in childhood. Annals of Allergy, Asthma \& Immunology, 90, 53-58.

http://dx.doi.org/10.1016/S1081-1206(10)61661-4

[16] Sugiyama, T., Sugiyama, K., Toda, M., Yukawa, T., Makino, S. and Fukud, T. (2002) Risk factors for asthma and allergic diseases among 13 - 14-year-old schoolchildren in Japan. Allergology International, 51, 139-150. http://dx.doi.org/10.1046/j.1440-1592.2002.00250.x

[17] Dubakienè, R., Šurkienè, G., Stukas, R., Pirmaitytè-Vilesko, J. and Kavaliûnas, A. (2008) Food allergies among 5 th-9th grade schoolchildren in Vilnius (Lithuania). Ekologija, 54, 1-4. http://dx.doi.org/10.2478/V10055-008-0001-5

[18] Nicolai, T., Pereszlenyiova-Bliznakova, L., Illi, S., Reinhardt, D. and von, M.E. (2003) Longitudinal follow-up of the changing gender ratio in asthma from childhood to adulthood: Role of delayed manifestation in girls. Pediatric Allergy and Immunology, 14, 280-283. http://dx.doi.org/10.1034/j.1399-3038.2003.00047.x

[19] Schatz, M., Clark, S., and Camargo Jr., C.A. (2006) Sex differences in the presentation and course of asthma hospitalizations. Chest, 129, 50-55. http://dx.doi.org/10.1378/chest.129.1.50

[20] Almqvist, C., Worm, M. and Leynaert, B. (2008) Impact of gender on asthma in childhood and adolescence: A GA2LEN review. Allergy, 63, 47-57.

[21] Griška, E., Kudzyte, J. and Bojarskas, J. (2009) Vaikų bronchų astmos, alerginio rinito ir atopinio dermatito paplitimo kaita Kaune 1994-2002 m. ISAAC I ir III fazès tyrimo duomenimis. Vaiku Pulmonologija ir Alergologija, 12, 4101-4112.

[22] Kudzyte, J., Griška, E. and Bojarskas, J. (2008) Time trends in the prevalence of asthma and allergy among 6 7-year-old children. Results from ISAAC phase I and III studies in Kaunas, Lithuania. Medicina (Kaunas), 44, 944-952.

[23] G. Šurkienè, R. Dubakienè, R. Stukas, V. Sudeikyte, and N. Janulevičiūtè, (2009) Home allergies among 5th-9th grade schoolchildren in Vilnius, Lithuania. Ekologija, 55, 226-230.

[24] Pyrhonen, K., Nayha, S., Kaila, M., Hiltunen, L. and Laara, E. (2009) Occurrence of parent-reported food hypersensitivities and food allergies among children aged 1-4 yr. Pediatric Allergy and Immunology, 20, 328-338. http://dx.doi.org/10.1111/j.1399-3038.2008.00792.x

[25] Griška, E. (2008) Vaikų bronchų astmos, alerginio rinito ir atopinio dermatito bei jų simptomu paplitimas ir kaita (ISAAC tyrimas). Kauno medicinos universitetas. Ref Type: Thesis/Dissertation.

[26] Flohr, C., Pascoe, D. and Williams, H.C. (2005) Atopic dermatitis and the "hygiene hypothesis": Too clean to be true? British Journal of Dermatology, 152, 202-216. http://dx.doi.org/10.1111/j.1365-2133.2004.06436.x

[27] Kummeling, I., Stelma, F.F., Dagnelie, P.C., Snijders, B.E., Penders, J., Huber, M., van, R.R., van den Brandt, P.A. and Thijs, C. (2007) Early life exposure to antibiotics and the subsequent development of eczema, wheeze, and allergic sensitization in the first 2 years of life: The KOALA Birth Cohort Study. Pediatrics, 119, e225-e231. http://dx.doi.org/10.1542/peds.2006-0896

[28] Foliaki, S., Pearce, N., Bjorksten, B., Mallol, J., Montefort, S. and von, M.E. (2009) Antibiotic use in infancy and symptoms of asthma, rhinoconjunctivitis, and eczema in children 6 and 7 years old: International study of asthma and allergies in childhood phase III. Journal of Allergy and Clinical Immunology, 124, 982-989. 
http://dx.doi.org/10.1016/j.jaci.2009.08.017

[29] Ip, S., Chung, M., Raman, G., Chew, P., Magula, N., DeVine, D., Trikalinos, T. and Lau, J. (2007) Breastfeeding and maternal and infant health outcomes in developed countries. Evidence Report/Technology Assessment (Full. Rep.), 1-186.

[30] Grimshaw, K.E., Allen, K., Edwards, C.A., Beyer, K., Boulay, A., van der Aa, L.B., Sprikkelman, A., Belohlavkova, S., Clausen, M., Dubakiene, R., Duggan, E., Reche, M., Marino, L.V., Norhede, P., Ogorodova, L., Schoemaker, A., Stanczyk-Przyluska, A., Szepfalusi, Z., Vassilopoulou, E., Veehof, S.H., Vlieg-Boerstra, B.J., Wjst, M. and Dubois, A.E. (2009) Infant feeding and allergy prevention: A review of current knowledge and recommendations. A EuroPrevall state of the art paper. Allergy, 64, 1407-1416.

http://dx.doi.org/10.1111/j.1398-9995.2009.02172.x

[31] Jusienè, R., Breidokienè, R.,Èekuolienè, D., Markūnienè, E., Širvinskienė, G., Zamalijeva, O. and Žemaitienè, N. (2011) Žindymo reikšmš vaikų iki vienų metų amžiaus sveikatai. Visuomenès Sveikata, 1, 116-124.

[32] Kerkhof, M., Koopman, L.P., van Strien, R.T., Wijga, A., Smit, H.A., Aalberse, R.C., Neijens, H.J., Brunekreef, B.,
Postma, D.S. and Gerritsen, J. (2003) Risk factors for atopic dermatitis in infants at high risk of allergy: The PIAMA study. Clinical \& Experimental Allergy, 33, 1336-1341.

http://dx.doi.org/10.1046/j.1365-2222.2003.01751.x

[33] Host, A., Halken, S., Muraro, A., Dreborg, S., Niggemann, B., Aalberse, R., Arshad, S.H., von, B.A., Carlsen, K.H., Duschen, K., Eigenmann, P.A., Hill, D., Jones, C., Mellon, M., Oldeus, G., Oranje, A., Pascual, C., Prescott, S., Sampson, H., Svartengren, M., Wahn, U., Warner, J.A., Warner, J.O., Vandenplas, Y., Wickman, M. and Zeiger, R.S. (2008) Dietary prevention of allergic diseases in infants and small children. Pediatric Allergy and Immunology, 19, 1-4.

[34] Liem, J.J., Kozyrskyj, A.L., Huq, S.I. and Becker, A.B. (2007) The risk of developing food allergy in premature or low-birth-weight children. Journal of Allergy and Clinical Immunology, 119, 1203-1209. http://dx.doi.org/10.1016/j.jaci.2006.12.671

[35] Apfelbacher, C.J., Diepgen, T.L. and Schmitt, J. (2011) Determinants of eczema: Population-based cross-sectional study in Germany. Allergy, 66, 206-213. http://dx.doi.org/10.1111/j.1398-9995.2010.02464.x 